\title{
Evaluation of the Above-Ground Biomass of Steppe Ecosystems According to Their Stage of Degradation: Case of the Area of Ain Skhouna (Western Algeria)
}

\author{
Abdeslam Morsli ${ }^{1,2}$, Okkacha Hasnaoui ${ }^{2,3}$, Fatiha Arfi ${ }^{1,2}$ \\ ${ }^{1}$ INRF Ain-Skhouna, Saida, Algeria \\ ${ }^{2}$ Laboratory of Ecology and Natural Ecosystem Management, University of Tlemcen, Tlemcen, Algeria \\ ${ }^{3}$ Faculty of Science, University of Dr Tahar Moulay, Saida, Algeria \\ Email: okhasnaoui2001@yahoo.fr
}

Received 28 February 2016; accepted 17 April 2016; published 20 April 2016

Copyright (C) 2016 by authors and Scientific Research Publishing Inc.

This work is licensed under the Creative Commons Attribution International License (CC BY). http://creativecommons.org/licenses/by/4.0/

(c) (i) Open Access

\begin{abstract}
The steppe in the region of Ain Skhouna (Department of Saida) includes three major vegetation types: Stipa tenacissima, Artemisia herba alba and Lygeum spartum. They have a very important ecological and socio-economic role. Nevertheless, they are exposed to a threat of deterioration due essentially to a combination of adverse climate circumstances and human impact. In the field, we found three physiognomic stages for each type of vegetation: degraded, moderately degraded and well growing. For a better comprehension of the process of each facies, we considered that the dynamic of the above-ground biomass is an interesting indicator for quantifying the degree of degradation of the steppic ecosystems. For that, we have adopted a combined method: linear transects and vegetation harvests over a one-square meter surface. This approach allowed us to identify the chosen site taxa on the one hand and quantify the above-ground biomass of each plot on the other hand. The obtained results reveal a significant regression of the above-ground biomass when moving from one site to another. The values about the Stipa formations present an average biomass oscillating between 1024 and $271.7 \mathrm{~kg}$ DM/ha for perennial species and between 367 and $68.8 \mathrm{~kg} \mathrm{DM} / \mathrm{ha}$ for annuals. Those about Artemisia formations fluctuate between 3584 and $805 \mathrm{~kg}$ $\mathrm{DM} / \mathrm{ha}$ for perennials and between 524 and $66 \mathrm{~kg} \mathrm{DM} / \mathrm{ha}$ for annuals. Those about Lygeum formations oscillate between 274.4 and $87.9 \mathrm{~kg} \mathrm{DM} / \mathrm{ha}$ for perennial species accompanying Lygeum spartum and between 162.3 and $31.6 \mathrm{~kg} \mathrm{DM} / \mathrm{ha}$ for annuals.
\end{abstract}

\section{Keywords}

Vegetation, Evaluation, Biomass, Degradation, Ain Skhouna, Algeria

How to cite this paper: Morsli, A., Hasnaoui, O. and Arfi, F. (2016) Evaluation of the Above-Ground Biomass of Steppe Ecosystems According to Their Stage of Degradation: Case of the Area of Ain Skhouna (Western Algeria). Open Journal of Ecology, 6, 235-242. http://dx.doi.org/10.4236/oje.2016.65024 


\section{Introduction}

Algerian steppes are dominated by four major types of vegetation: the graminean steppes based on alfa (Stipa tenacissima) and esparto (Lygeum spartum), which are mediocre courses; the chamaephytiques steppes based on sagebrush (Artemisia herba alba) whose pastoral values are very significant and Hamada scoparia that is found on the regs [1].

All the steppe formations are used as fodder resources and are overexploited by both herds and population [2]. The "alfa sea" described by Trabut [3] and whose area was estimated at 3,976,174 hectares by the general government of Algeria in 1921 has been reduced to 2,025,864 hectares [4]. Therefore, in 70 years, the alfa area fell by half.

The pressure on these resources, in the absence of a rational development policy of steppe rangelands, seriously compromises the survival of indigenous species of the steppes. The anthropogenic pressure exerted on this space results in a decrease in biomass with all ecological and socioeconomic consequences. Recently the works of Hasnaoui et al. [5] [6], Henni [7], Chaalane et al. [8] show a regressive dynamics of steppe formations.

In order to increase the corpus of data on vegetation dynamics, we considered it important to work on aboveground biomass of three differently affected facies in the region of Ain Skhouna (Department of Saida). This approach allowed us to quantify the above-ground biomass of Stipa, sagebrush and esparto formations. This process is a means to identify the threats to the ecosystems in the study area.

\section{Study Area}

The region of Ain-Skhouna covers an area of $500 \mathrm{~km}^{2}$; it is located on the high plains of Western North, along the Eastern part of Chott Chergui (Figure 1). It is bounded to the South by the municipality of Rogassa (Department of El Bayadh), North-east by the department of Tiaret and North-west by the municipality of Maamora (Department of Saida).

The analysis of rainfall over a period of sixty six (66) years at the meteorological station of Ain Skhouna gives an annual average of $281 \mathrm{~mm}$. The rainiest months are between September and May, which corresponds to over $75 \%$ of the average annual rainfall (Figure 2).

The minimal average yearly temperatures are recorded in the month of January $\left(2.5^{\circ} \mathrm{C}\right)$ and the maximal ones in July and August $\left(36^{\circ} \mathrm{C}\right)$. The evapotranspiration (ETP) is quite important during the period extending from May to September. The value of ETP recorded in July equals $173.3 \mathrm{~mm}$ and that of August is $163.4 \mathrm{~mm}$ [9].

The soils are developed on a substrate made of limestone crust, silt, clay, marl and red clay). Sandy soils are located at the edges of the Chott (wind intake) and alluvial soils (deeper) cover only some depressions. This edaphic diversity enables the development of a quite interesting floristic diversity.

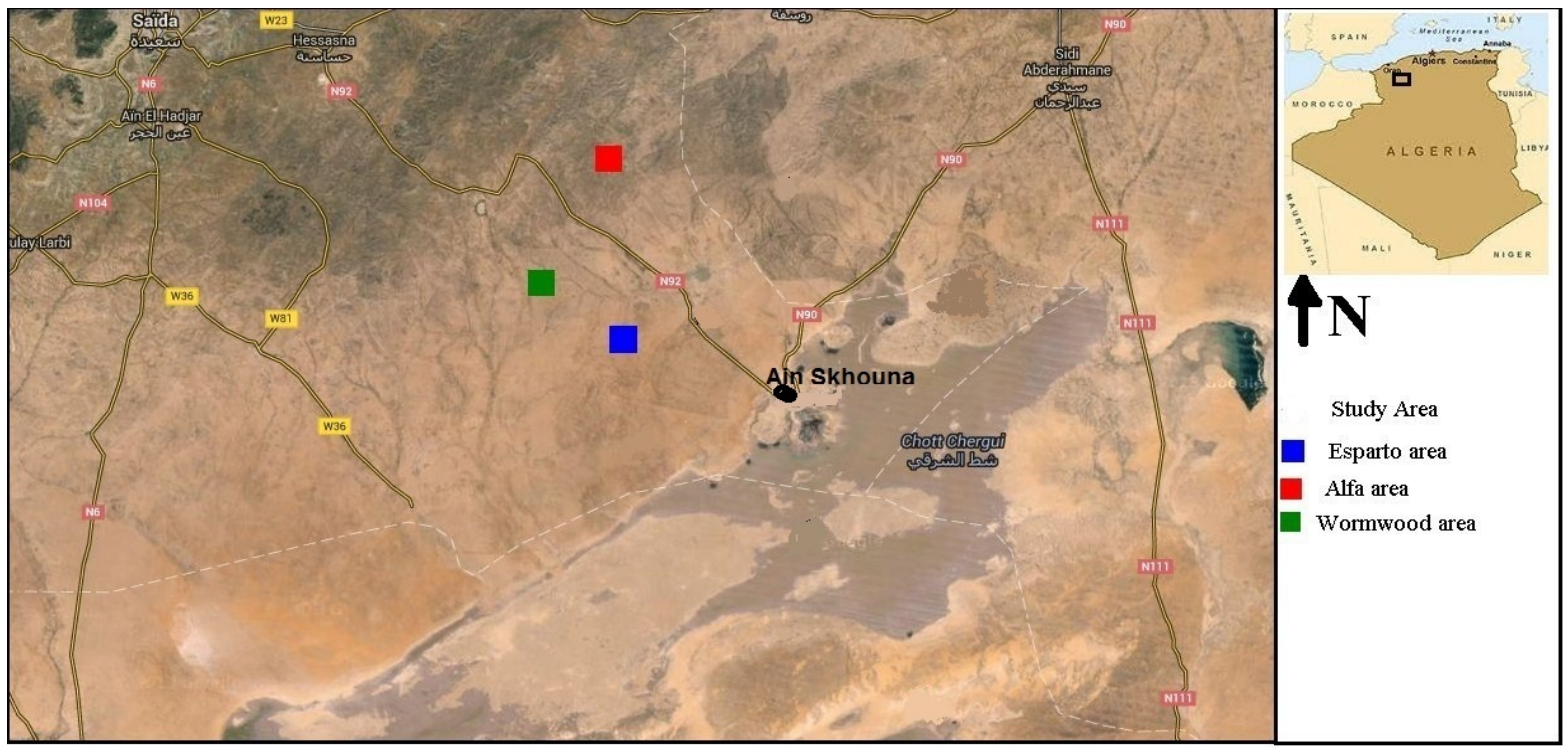

Figure 1. Location of the study area (Hasnaoui et al. modified [5]). 
The population of the area is experiencing a significant increase; it had gone from 4500 inhabitants in 1977 to 7272 in 2009 and is currently around 10,000 among whom 1800 in the agglomeration of Zeraguet, 500 nomads and 800 in scattered areas. The economy of the region revolves mainly around agriculture and livestock with a herd totaling 15,000 sheep equivalents held by 600 farmers and 100 breeders. The anthropic pressure on the steppe vegetation is strong since the grazing load is higher than 5 sheep equivalent/ha while the availability rate is of only 0.5 [10].

\section{Materials and Methods}

To assess the biomass of the three dominant vegetations in the steppe, an ecological zoning was carried out through different outings and allowed us to characterize the vegetation on the one hand and the stress suffered by floristic diversity on the other hand.

The choice of the stations was motivated by the physiognomic state of the dominant formation facies in the study area.

Three facies have been identified: 1) Degraded (D); 2) moderately degraded (M.D); 3) well growing (B.V) (Table 1).

An aleatory sampling and plots of $100 \mathrm{~m}^{2}$ were chosen to perform our monitoring on the field. The selected parcels are part of homogeneous areas and meet the criteria set by Godron [11]. The estimating of above-ground biomass was made for the three major species (Stipa tenacissima, Artimisia herba alba and Lygeum spartum) in their three facies selected for their degree of degradation (D; M.D and B.V). For reliable results we did 10 repetitions per facies or 90 steps in total. The weight of the above-ground biomass was estimated thanks to a 1000 gram precision scales.

The extrapolation of the results obtained per hectare allowed us to characterize the biomass of the perennial and annual species that are generally used as steppe rangeland fodder resources in the region of Ain-Skhouna. All facies were geo-referenced (Table 1).

The vegetal species found on each site were identified using the determining keys of Quézel and Santa [12]. The numerical processing was carried out with the help of the Version15 Minitab software.

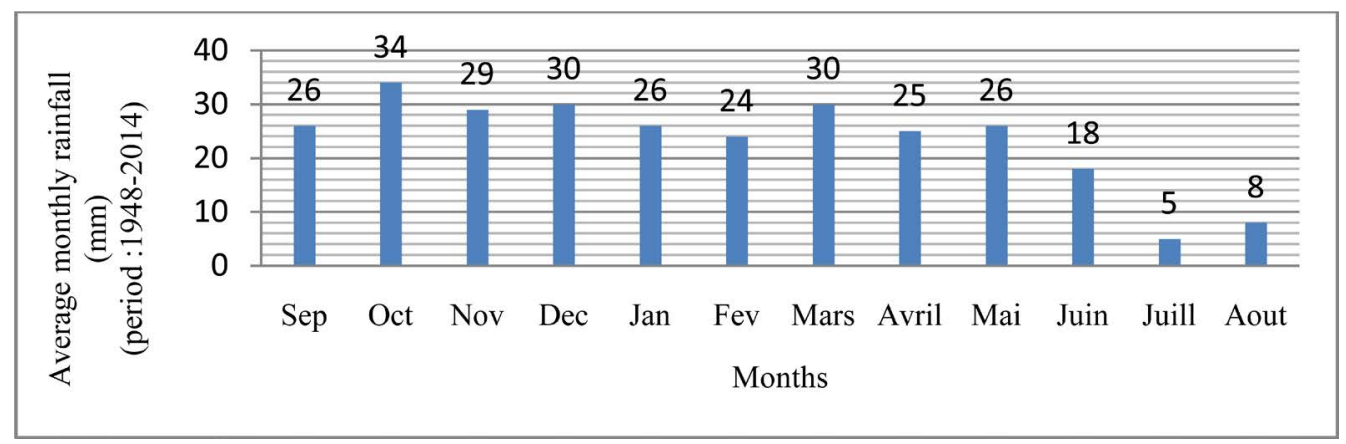

Figure 2. Average monthly rainfall in the study area.

Table 1. Geographical location of the study stations.

\begin{tabular}{|c|c|c|c|c|c|}
\hline Stations & Facies types & \multicolumn{2}{|c|}{ Geographical situation } & Altitude (m) & Recovery rate \% \\
\hline \multirow{3}{*}{ Stipa tenacissima } & A.B.V & $34^{\circ} 39^{\prime} 03^{\prime \prime}$ & $0^{\circ} 36^{\prime} 06^{\prime \prime}$ & 1092 & $50 \%-75 \%$ \\
\hline & A.M.D & $34^{\circ} 39^{\prime} 06^{\prime \prime}$ & $0^{\circ} 33 ' 38^{\prime \prime}$ & 1056 & $30 \%-50 \%$ \\
\hline & A.D & $34^{\circ} 41^{\prime} 05^{\prime \prime}$ & $0^{\circ} 36^{\prime} 10^{\prime \prime}$ & 1023 & Inferior to $30 \%$ \\
\hline \multirow{3}{*}{ Artemisia herba alba } & B.V & $34^{\circ} 40^{\prime} 15^{\prime \prime}$ & $0^{\circ} 41^{\prime} 34^{\prime \prime}$ & 1056 & $50 \%-75 \%$ \\
\hline & M.D & $34^{\circ} 36^{\prime} 15^{\prime \prime}$ & $0^{\circ} 43^{\prime} 38^{\prime \prime}$ & 1023 & $30 \%-50 \%$ \\
\hline & $\mathrm{D}$ & $34^{\circ} 40^{\prime} 58^{\prime \prime}$ & $0^{\circ} 39 ' 15^{\prime \prime}$ & 1020 & Inferior to $30 \%$ \\
\hline \multirow{3}{*}{ Lygeum spartum } & B.V & $34^{\circ} 33^{\prime} 40^{\prime \prime}$ & $0^{\circ} 47^{\prime} 50^{\prime \prime}$ & 1027 & $50 \%-75 \%$ \\
\hline & M.D & $34^{\circ} 35^{\prime} 03^{\prime \prime}$ & $0^{\circ} 41^{\prime} 45^{\prime \prime}$ & 1082 & $30 \%-50 \%$ \\
\hline & $\mathrm{D}$ & $34^{\circ} 30^{\prime} 11^{\prime \prime}$ & $0^{\circ} 44^{\prime} 54^{\prime \prime}$ & 1029 & Inferior to $30 \%$ \\
\hline
\end{tabular}

B.V: well growing facies; M.D: moderately degraded facies; D: degraded facies. 


\section{Results and Discussion}

\subsection{Above-Ground Biomass of Stipa Facies}

The results obtained in the three facies show a clear difference between facies. The facies A.B.V presents an average biomass of $1024 \mathrm{~kg} \mathrm{DM} / \mathrm{ha}$ for perennials and $367 \mathrm{~kg} \mathrm{DM} / \mathrm{ha}$ for annuals; the average value of A.M.D is $651 \mathrm{~kg} \mathrm{DM} / \mathrm{ha}$ for perennials and $160.7 \mathrm{~kg} \mathrm{DM} / \mathrm{ha}$ for annuals; however A.D. presents a 271.7 value for perennials and $68.8 \mathrm{~kg} \mathrm{DM} / \mathrm{ha}$ for annuals.

We noted that the annual plants still represent a significant fodder resource despite the difficult environmental conditions in which they develop (Table 2).

It should be noted that the Stipa areas which are seen as being in good condition, are in fact, in alarming regression. Indeed, the above-ground biomass estimated at $2100 \mathrm{~kg}$ DM/ha in 1976 [13], fell to $1750 \mathrm{~kg} \mathrm{DM} / \mathrm{ha}$ in 1996 [14] and $1500 \mathrm{~kg} \mathrm{DM} / \mathrm{ha}$ [15].

In the same context Bouchetata T. and Bouchetata A. [16] estimated the alfa above-ground biomass at 1254 $\mathrm{kg} \mathrm{DM} / \mathrm{ha}$. The spatiotemporal evolution of biomass (Figure 3; Figure 4) is the result of several factors including the irrational rangeland management and the introduction of means and development techniques unsuited to steppe environments.

Today the steppe above-ground biomass is continually declining. The comparative analysis of the obtained results in the various selected stations (Figure 3; Figure 4) shows an alarming regressive dynamics. The ecological balance of these steppes is already broken. The works of Hasnaoui and Bouazza [17] reveal that many species belonging to the facies have disappeared and others have become rare.

The recorded average values show a continuous decline of above-ground biomass when compared to the re-

Table 2. Evolution of the above-ground biomass of Stipa facies.

\begin{tabular}{|c|c|c|c|c|c|c|}
\hline \multirow{2}{*}{ List } & \multicolumn{2}{|c|}{ A.B.V } & \multicolumn{2}{|c|}{ A.M.D } & \multicolumn{2}{|c|}{ A.D } \\
\hline & $\mathrm{AL}$ & $\mathrm{AN}$ & $\mathrm{AL}$ & AN & $\mathrm{AL}$ & AN \\
\hline $\mathrm{R} 1$ & 1300 & 500 & 900 & 200 & 350 & 80 \\
\hline $\mathrm{R} 2$ & 1100 & 400 & 650 & 150 & 290 & 70 \\
\hline R3 & 900 & 250 & 700 & 162 & 280 & 65 \\
\hline $\mathrm{R} 4$ & 1000 & 300 & 690 & 165 & 310 & 80 \\
\hline R5 & 800 & 350 & 550 & 162 & 300 & 75 \\
\hline R6 & 1100 & 400 & 590 & 159 & 250 & 49 \\
\hline R7 & 1000 & 380 & 580 & 150 & 259 & 63 \\
\hline R8 & 1000 & 290 & 600 & 154 & 220 & 69 \\
\hline R9 & 900 & 500 & 620 & 156 & 223 & 70 \\
\hline R10 & 1140 & 300 & 630 & 149 & 235 & 65 \\
\hline Average & 1024 & 367 & 651 & 160.7 & 271.7 & 68.6 \\
\hline
\end{tabular}

A.B.V: well growing facies; A.M.D: moderately degraded facies; A.D: degraded facies; AL: alfa; AN: annuals species.

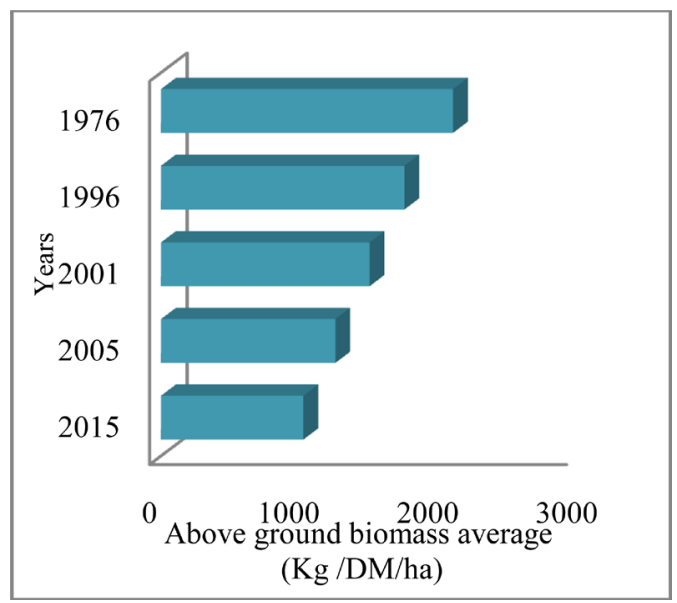

Figure 3. Regressive evolution of alfa biomass. 


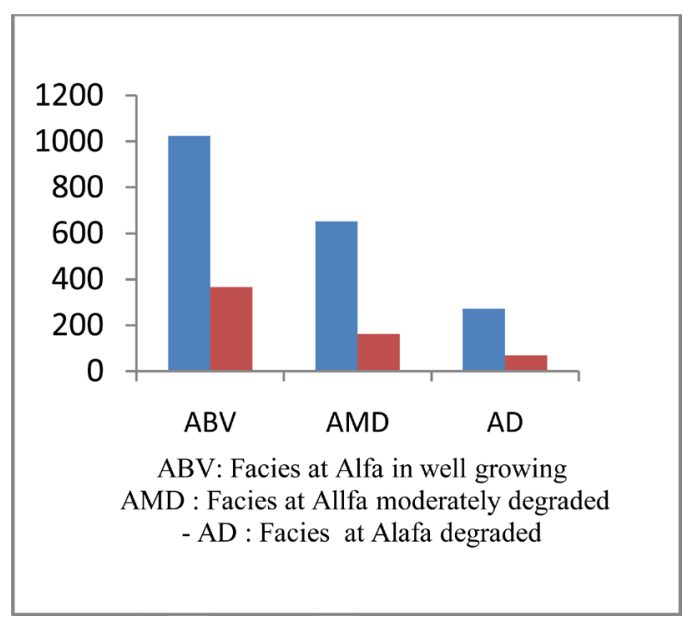

Figure 4. State of the alfa biomass according to the facies state.

Table 3. Above-ground biomass at Artemisia in the region of Ain-Skhouna.

\begin{tabular}{ccccccc}
\hline List & \multicolumn{3}{c}{ AR.B.V } & \multicolumn{2}{c}{ AR. M.D } & \multicolumn{2}{c}{ AR. D } \\
\cline { 2 - 7 } & AR & AN & AR & AN & AR & AN \\
R1 & 3500 & 600 & 2600 & 200 & 1000 & 90 \\
R2 & 4000 & 460 & 2350 & 150 & 950 & 85 \\
R3 & 2500 & 550 & 1950 & 180 & 830 & 70 \\
R4 & 2300 & 530 & 2430 & 199 & 700 & 71 \\
R5 & 4000 & 560 & 2350 & 210 & 730 & 62 \\
R6 & 3500 & 490 & 2670 & 200 & 690 & 53 \\
R7 & 4300 & 520 & 2900 & 211 & 790 & 56 \\
R8 & 4390 & 535 & 1750 & 213 & 680 & 55 \\
R9 & 4350 & 499 & 1880 & 190 & 1100 & 60 \\
R10 & 3000 & 500 & 1780 & 188 & 580 & 62 \\
Average & 3584 & 524.4 & 2266 & 194.1 & 805 & 66.4 \\
\hline
\end{tabular}

AR. B.V: Sagebrush well-growing facies; AR. M.D: Sagebrush moderately degraded facies; AR. D: Sagebrush degraded facies; AR: Sagebrush; AN: annuals species.

sults obtained by other researchers in 1992, 1996, 2001 and 2005. This regressing evolution of alfa and the species in the facies A.B.V focuses on the retrogression of the vegetation cover in the study area. A decline of 373 $\mathrm{kg} \mathrm{DM} / \mathrm{ha}$ was found between A.B.V and A.M.D and $753 \mathrm{~kg}$ DM/ha between A.B.V and A.D. The present appearance of alfa steppes of Ain Skhouna region reveals a worrying situation. The causes of the weakening fodder production units are linked to the population growth in the area and the socio-economic activities which are continuously growing every year.

\subsection{Above-Ground Biomass of Artemisia Facies}

The above-ground biomass results that were obtained in the Artemisia herba alba facies (Table 3) show that the facies B.V presents an average above-ground biomass of $3584 \mathrm{~kg} \mathrm{DM} / \mathrm{ha}$ and falls to $805 \mathrm{~kg} \mathrm{DM} / \mathrm{ha}$ in A.D facies owing to the reduction of sagebrush vegetation cover and the proliferation of degrading species such as Atractylis serratuloides, Peganum harmala and Noaea mucronata.

The works of Djebaili [18]; Le Houérou [19]; Benabdeli [20] and Nedjraoui [15] show the regressive state of sagebrush steppes. The above-ground biomass of these facies was valued to $4500 \mathrm{~kg} \mathrm{DM} / \mathrm{ha}$. The comparison of our results with those researchers' reveals a decline of $1000 \mathrm{~kg}$ DM/ha in the AR. B.V. a very significant decline was observed in our measurements when moving from one facies to another (Figure 5).

\subsection{Above-Ground Biomass of Lygeum Facies}

The different above-ground biomass measurements made on the 3 esparto facies show that these formations are 
in general of low productivity (Figures 6-8). The average above-ground biomass of B.V facies is $301.10 \mathrm{~kg}$ $\mathrm{DM} /$ ha for esparto and 162.3 for annuals species.

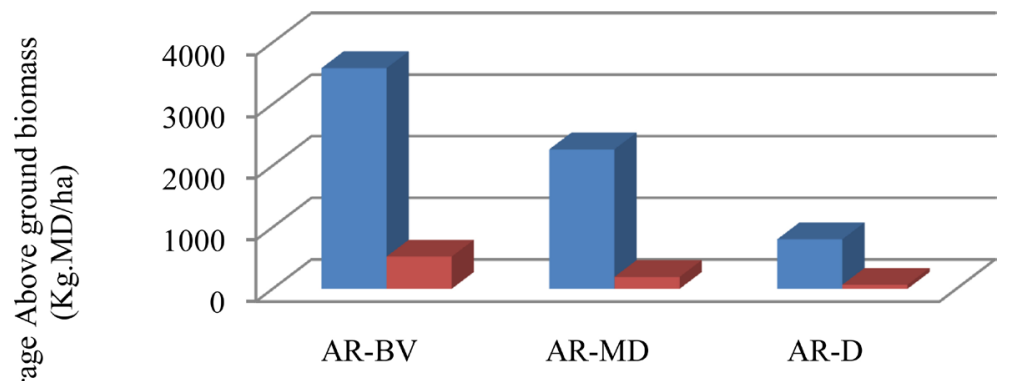

AR.BV : Facies at sagebrush well coming - AR.MD : Facies at sagebrush moderately degraded - AR.D : Facies at sagebrush...

Figure 5. Evolution of the biomass in different facies of Artemisia herba alba.

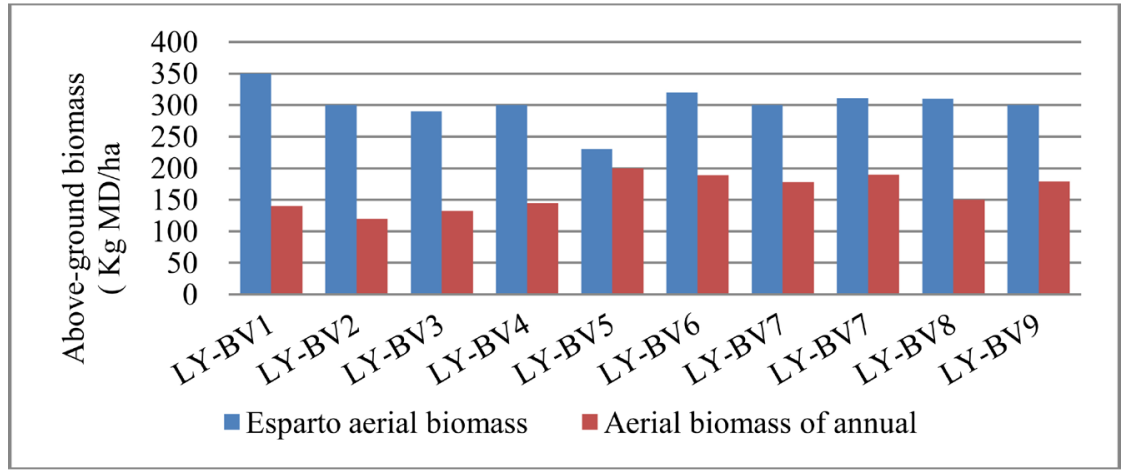

Figure 6. Above-ground biomass of well growing Lygeum spartum facies (LY-BV).

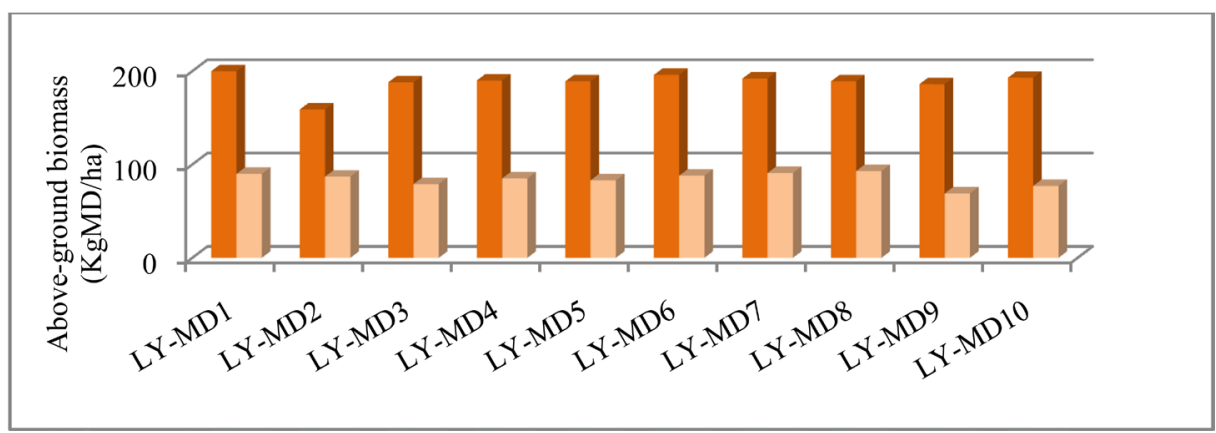

Figure 7. Above-ground biomass of moderately degraded Lygeum spartum facies.

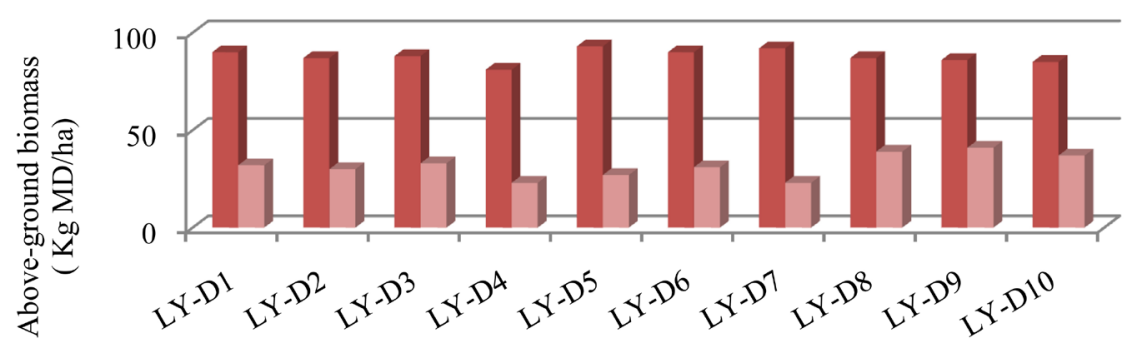

Figure 8. Above-ground biomass of degraded Lygeum spartum facies. 
Le Houérou [19]; Benabdeli [20]; Nedjraoui [15] estimated the biomass at $500 \mathrm{~kg}$ DM/ha for B.V facies and they noted a relatively important floristic diversity in annuals and/or perennials and their biomass was estimated at $110 \mathrm{~kg} \mathrm{DM} /$ ha. Our results show that the current state of these ecosystems is in continual regressive evolution and the recorded biomass in B.V has now halved.

Our results confirm those of Aidoud and Touffet [14], Hasnaoui et al. [6], Hasnaoui and Bouazza [17], Charrier [21], Monjauze [22], Roselt/Algeria [23].

The steppe formations in the study area are exposed to a decline in the vegetation cover of all the facies (Stipa, Artemisia and Lygeum). Today we are witnessing a changing physiognomy of ecosystems in the high steppe plains. The state of degradation is spreading and many species are either extinct or endangered [6]. Man's actions are the main causes of the degradation process of the vegetation and cause a change in the vegetation of the Saida region both qualitatively and quantitatively.

\section{Conclusions}

The obtained results on the quantification of above-ground biomass of the different structuring high steppe plains confirm the important regression of steppe ecosystems in the unprotected areas, leading to all sorts of disastrous ecological and socioeconomic consequences. The biomass in all the studied formations shows a very significant decrease.

The average decline is about $82 \%$ when moving from the B.V (well-growing) facies to the degraded facies. Currently, the alfa above-ground biomass represents only 58.5\% of what it used to be in 1996 (a decline of 41.5\%). The expression “alfa sea” that was so commonly heard in the early 1970's is not used any longer [5]. This is an indicator to warn about the susceptibility of these ecosystems to silting because of the low ground cover on one hand and the exposition of the edaphic resources to water and wind erosion on the other hand.

It is true that many national programs for steppe development have been developed so far to enhance the potential steppe ecosystems; nevertheless some of them have experienced many constraints, mostly related to malfunction between the objectives and the means implemented.

For the time being, the integration of agro-pastor and the limited studies without a global vision for a wider development is unfortunately the only adopted means for the steppe ecosystems reconstitution. To face the climate changes and the strong man's pressure and, thus, in order to limit the loss of the native vegetal species on steppe plants in the region of Ain Skhouna, emergency measures must be taken by the relevant authorities.

\section{References}

[1] Nedjraoui, D. and Bedrani, S. (2008) Desertification in the Algerian Steppes. Causes, Impacts and Actions to Fight; VertigO, 8. http://vertigo.revues.org/5375

http://dx.doi.org/10.4000/vertigo.5375

[2] Benabdeli, K., Benguerai, A. and Yerou, H. (2008) L'utilisation de l'espace steppique comme terrain de parcours entre identification, potentialités, utilisation et contraintes socio-écologiques en Algérie. Revue de l'écologie-environnement No. 04, 54-67.

[3] Trabut, L. (1889) Etude sur l’alfa. Jourdan, Alger, 90 p.

[4] CNTS (1989) Inventaire des nappes alfatières des wilayates. Rapport CNTS, 15 p.

[5] Hasnaoui, O., Benmansour, D. and Thinon M. (2011) Contribution à l'étude édapho-floristique de la dégradation des steppes à alfa (Stipa tenacissima L.) dans le Sud oranais : Cas de la commune de Maamoura ; Wilaya de Saida (Algérie Occidentale). Bulletin de la Societe Linneenne de Provence, 62, 157-165.

[6] Hasnaoui, O., Meziane, H., Borsali, A.H. and Bouazza, M. (2014) Evaluation of Characteristics Floristico-Edaphic of the Steppes at Alfa (Stipa tenacissima L.) in the Saida Region (Western Algeria). Open Journal of Ecology, 4, 883891. http://dx.doi.org/10.4236/oje.2014.414074

[7] Henni, M. (2014) Spatio-Temporal Evolution of Vegetation and Soil in Atriplex canescens and Role of Species in Improving Feed Provides Degraded Steppe Rangelands of the Wilaya of Saida (Western Algeria). Ph.D. Thesis, University of Sidi Bel-Abbes, Algeria, 129 p.

[8] Chalane, F., Mehdadi, Z., Hamdaoui, M. and Hasnaoui, O. (2015) Evaluation of Plant Diversity and Edaphic Characteristics of the Steppe Alfa (Stipa tenacissima) of the Saida Area (western Algeria). European Journal of Scientific Research, 128, 265-276.

[9] Moulay, A. (2013) Contribution à l’étude de la régénération naturelle et artificielle de Stipa tenacissima L. dans la 
région steppique occidentale (Algérie). $\mathrm{PhD}$, Institute of Biology University of Mascara, $172 \mathrm{p}$.

[10] Benabdeli, K. (2000) Assessing the Impact of New Farming Methods on Space and the Environment Steppic: Municipality of Ras El Ma (Sidi Bel Abbes-Algeria). Mediterranean Option Sér, A/ $\mathrm{N}^{\circ} 39$.

[11] Godron, M. (1984) Ecology of Terrestrial Vegetation. Masson and $C^{\text {ie }}$ Edit., Paris, 197 p.

[12] Quézel, P. and Santa, S. (1962) New Flora of Algeria and the Southern Desert Regions. CNRS, Paris, 1170 p.

[13] Aidoud, A. and Nedjraoui, D. (1992) The Steppes of Alfa (Stipa tenacissima L) and Their Utilisation by Sheeps. In Plant Animal Interactions in Mediterrean-Type Ecosystems. MEDECOS VI, Gréce, 62-67.

[14] Aidoud, A. and Touffet, J. (1996) Regression of Alfa (Stipa tenacissima), Perennial Grass, a Desertification Indicator of Algerian Steppe. Sécheresse, No. 7, 187-193.

[15] Nedjraoui, D. (2001) Le profil fourrager de l’Algérie. Rapport URBT Alger.

[16] Boucheta, T. and Boucheta, A. (2005) Degradation of Steppe Ecosystems and Sustainable Development Strategy. Methodological Development Applied to the Wilaya of Naama (Algeria). Review Sustainability and Territory, 5. http://developpementdurable.revue.org/1339

[17] Hasnaoui, O. and Bouazza, M. (2015) Indicateurs de dégradation des bio-ressources naturelles de l’Algérie occidentale: Cas de la steppe de la wilaya de Saida. Algerian Journal of Arid Environment, 5, 63-75.

[18] Djebaili, S. (1984) Algerian Steppe: Phytosociology and Ecology, O.P.U Edit, Alger OPU, Alger, 177 p.

[19] Le Houerou, H.N. (1985) La régénération des steppes algériennes. Rapport de mission de consultation et dévaluation. Ministère de l'agriculture, Alger, 37 p.

[20] Benabdeli, K. (1996) Impact socio-économique et écologie de la privatisation des terres sur la gestion des espaces et la conduite des troupeaux : cas de la commune de Télagh (Algérie). Option méditerranéenne, No. 32, 185-194.

[21] Charrier, C. (1873) Alfa Highlands Algeria. Algeria Agricole, 32 p.

[22] Monjauze, A. (1947) La touffe d’Alfa. Archives du Gouvernement Général d’Algérie. Volume 1 multi-graphe, 29 p.

[23] Roselt/Algérie (2005) Observatoire des Hautes plaines steppiques, Bilan final du projet Roselt/OSS (2002-2005), USTHB-CRSTRA, 135 p. 